\title{
PERAN GURU PENDIDIKAN AGAMA KRISTEN DALAM PEMBENTUKAN KARAKTER PESERTA DIDIK DI SEKOLAH
}

\author{
Carinamis Halawa, ${ }^{1}$ Peni Hestiningrum, ${ }^{2}$ Iswahyudi $^{3}$ \\ Sekolah Tinggi Teologi Moriah, Indonesia ${ }^{123}$ \\ Email: pakyudi@gmail.com ${ }^{3}$
}

\begin{abstract}
The formation of the character of these students in an education will affect the development without paying attention to the ethics, character and morals of a student's behavior. So in this case it is very necessary or needed attention from various parties, especially in learning and teaching with the aim of helping students to get to know the world of education from those who don't know to know, especially in knowing the truth of God. As a teacher of Christian religious education, this must be influential in shaping the character in the ethical and moral supervision of students. These students are partially affected by the problem of character crises, because where they are not controlled or uncontrolled in the influence of the development of science and technology, in this case the environmental conditions will be able to affect the character of students. However, in this situation it will be very worrying in shaping that character, not only as parents, teachers, but also as churches in educational institutions. Therefore, as a Christian religious education teacher will be expected to shape the character and morals of students. Therefore, as a teacher, he will be able to carry out his duties with a sense of responsibility in accordance with the objectives of education in learning, namely forming and creating a generation that has noble character, competence, and responsibility in having Christ. As a teacher, he will bring these students to know how an environment is not affected in the formation of character in an education. Christian teachers will play an important role in shaping the character of students who are right and direct in a goal.
\end{abstract}

Keywords: Role of Teachers, Christian Religious Education, Character Building

\begin{abstract}
Abstrak
Pembentukan karakter peserta didik ini dalam suatu pendidikan akan berpengaruh pada perkembangan tanpa memperhatikan etika, karakter serta moral dari suatu perilaku peserta didik. Maka dalam hal ini sangat dibutuhkan atau diperlukan perhatian dari berbagai pihak terkhususnya dalam belajar dan mengajar dengan tujuan supaya menolong siswa untuk mengenal dunia pendidikan dari yang tidak tahu menjadi tahu, terlebih dalam mengenal kebenaran Allah. Sebagai guru pendidikan agama Kristen ini harus berpengaruh dalam membentuk karakter dalam pengawasan etika, dan moral dari peserta didik. Peserta didik ini sebagian mengalami pengaruh dalam masalah krisis karakter, karena dimana mereka tidak terkontrol atau tidak terkendalikan dalam pengaruh perkembangan ilmu pengetahuan dan teknologi, dalam hal ini keadaan lingkungan akan dapat mempengaruhi karakter peserta didik. Akan tetapi, dalam keadaan ini akan sangat mengkuatirkan dalam membentuk karakter tersebut, bukan hanya saja sebagai orang tua, guru, juga sebagai gereja dalam lembaga pendidikan. Oleh karena itu, sebagai guru pendidikan agama Kristen akan diharapkan dalam membentuk karakter dan moral siswa. Maka dari pada itu sebagai guru, akan mampu melaksanakan tugasnya dengan rasa tanggung jawab sesuai dengan tujuan pendidikan dalam pembelajaran yakni membentuk dan menciptakan generasi yang berakhlak mulia, berkompetensi, serta bertanggung jawab dalam memiliki kristus. Sebagai guru akan
\end{abstract}


membawa peserta didik tersebut dalam mengenal bagaimana suatu lingkungan tersebut tidak terpengaruh dalam pembentukan karakter dalam suatu pendidikan. Guru Kristen akan berperan penting dalam membentuk karakter peserta didik yang benar dan mengarahkan dalam suatu tujuan.

Kata Kunci: Peran Guru, Pendidikan Agama Kriten, Pembentukan Karakter

\section{PENDAHULUAN}

Berbicara tentang pengaruh guru agama Kristen ini dalam pembentukan karakter peserta didik, tidak lepas dengan pengaruh perkembangan ilmu pendidikan yang sangat membuat karakter peserta didik menjadi sampingan dan tidak ada perhatian atau fokus utama pada fenomena sosial, sehingga dapat mengakibatkan pada kondisi moral, dan karakter anak menjadi rusak. Ada faktor-faktor yang menentukan keberhasilan suatu pendidikan, salah satunya adalah peran guru. Guru memiliki peran yang penting dalam membantu mensukseskan pendidikan di sekolah. Guru memiliki tanggung jawab yang besar dalam menghasilkan siswa yang berkualitas dan juga memiliki karakter yang baik dan bermoral dalam pendidikan, guru tidak hanya berperan sebagai seorang pengajar tetapi guru juga harus menjadi contoh dan teladan yang baik bagi perkembangan peserta didik di sekolah. ${ }^{1}$

${ }^{1}$ Arozatulo Telaumbanua, "Peranan Guru Pendidikan Agama Kristen dalam Membentuk Karakter Siswa" (Jurnal Fidei Vol.1 No.2 November 2021) 221-222,
Guru agama Kristen ini akan mengajak dan menolong peserta didik untuk mengenal sang pencipta. Oleh karena itu, bukan hanya sebatas itu juga, tetapi guru juga mencari jalan keluar bagaimana cara memiliki karakter yang serupa dan segambar dengan Tuhan Yesus. Guru juga merupakan teladan bagi peserta didik di sekolah, karena sebagai guru agama Kristen ini dimampukan menjadi teladan karena duluan mengalami lahir baru yang akan dituntun oleh Roh Kudus sehingga guru pendidikan agama Kristen memiliki peranan yang besar dalam membentuk karakter yang benar dalam mengarahkan peserta didik untuk mengerti arah tujuan kehidupan ini yang sesungguhnya. Oleh sebab itu, menjadi seorang guru ini bukanlah satu hal yang muda karena merupakan pekerjaan atau pertanggunggjawaban yang paling penting dalam mengajar peserta didik, panggilan yang istimewa yang dikhususkan, berbeda dengan guru-guru yang lainnya, karena seorang pendidik yang mengajar dibidang

https://www.neliti.com/id/publications/270038/ tanggal 22 November 2021 
kekristenan akan membawa peserta didik untuk mengenal Kristus Yesus secara benar sesuai denga ajaran Alkitab dan mengarahkan kepada pembentukan karakter anak didik. ${ }^{2}$

Dalam pembentukan karakter akan menjadi hal yang sangat penting diajarkan kepada peserta didik sejak duduk dibangku sekolah sehingga mempengaruhi guru dalam membentuk sikap dan perilaku peserta didik karena guru harus menjadi model dan teladan bagi peserta didik dalam mengubah anak-anak tersebut supaya memiliki karakter yang baik dan benar. Dalam mengajar tersebut bukan hanya sekedar hanya tampil dan memberikan informasi atau ilmu pengetahuan pada peserta didik, tetapi harus mengajar lebih sekedar itu, sehingga tidak mempengaruhi anak tersebut dalam membentuk karakter dalam pendidikan. Guru memegang hal yang penting dan harus tampil menjadi contoh yang baik bagi peserta didik, karena guru itu harus mempunyai tanggung jawab untuk melihat segala sesuatu didalam kelas dalam membantu proses perkembangan pendidikan seorang anak didik. Oleh sebab itu, guru mempunyai pengaruh yang sangat penting dalam membentuk karakter peserta didik dalam setiap individu

\footnotetext{
${ }^{2}$ Situmorang Kasminton, Pengaruh Guru dalam Membentuk Karakter, (Jurnal Teologi dan Pendidikan, Agama Kristen, Vol. 42018 )" 104
}

masing-masing dalam membawa anakanak tersebut untuk meningkatkan derajat dalam pendidikan.

Pada metode Penelitian yang akan dilakukan adalah bersifat penelitian kepustakaan (library research), yaitu dengan mengumpulkan data-data yang berhubungan dengan tema yang dibahas. Sumber primer seperti buku, jurnal ilmiah, dan lain-lain dimanfaatkan untuk membangun konsep tentang pengaruh guru dalam pembentukan peserta didik sebagai model pembelajaran alternatif di era digital. ${ }^{3}$ Konsep-konsep dianalisis dengan cara mencermati keterkaitan, kesamaan, dan kesesuaian dengan topik.

\section{PEMBAHASAN}

Peran guru sebagai pendidik agama Kristen

Guru merupakan orang yang dipercayakan Tuhan dalam melaksanakan pendidikan dan pengajaran sesuai dengan karunia yang teleh diberikan kepadanya dalam membentuk peserta didik. Guru merupakan salah satu komponen yang ikut berpengaruh dalam membentuk karakter peserta didik dalam ilmu pengetahuan dan

\footnotetext{
${ }^{3}$ Sugiyono, Metode Penelitian Kombinasi (Bandung: Alfabeta, 2011), 339-343.
} 
memegang peranan penting dalam ilmu pendidikan. $^{4}$

Guru adalah orang yang memberikan ilmu pengetahuan kepada peserta didik. Guru dalam pandangan masyarakat adalah orang yang melaksanakan pendidikan di tempat-tempat tertentu, tidak mesti di lembaga pendidikan formal, tetapi bisa juga di gereja, di rumah dan sebagainya. Pembelajaran merupakan perpaduan dari dua aktivitas, yaitu: aktivitas mengajar dan aktivitas belajar. "Aktivitas mengajar menyangkut peran guru dalam konteks mengupayakan terciptanya jalinan komunikasi yang harmonis inilah yang menjadi indikator suatu aktivitas proses pengajaran itu akan berjalan dengan baik."

Guru pendidikan agama Kristen merupakan sosok pemimpin yang terpanggil untuk menjadi pengajar, pembimbing, pendidik umat-Nya, supaya memiliki rasa takut akan Tuhan. "Guru pendidikan agama Kristen merupakan figur yang bertanggung jawab untuk membina dan memajukan hidup rohani

${ }^{4}$ Djmarah Bahri Syaifu., Guru dan Anak didik dalam Interaksi Edukatif. (Jakarta: PT. Renika Cipta, 2005),

${ }^{5}$ Ahmad Rohani, Pengelolaan Pengajaran, (Jakarta: Rineka Cipta, 2010), 5; Imron Widjaja dan Lasmaria Nami Simanungkalit. "Christian Religious Education Management, Government Service, In Cell Groups On The Quality Of The Faith Of Church Members In Indonesia Bethel Church Of Graha Pena." MAHABBAH: Journal of Religion and Education 1, no.1 (2020): 55-69. https://doi.org/10.47135/mahabbah.v1i1.8. dan iman peserta didik." ${ }^{, 6}$ Guru pendidikan agama Kristen, sebaiknya memahami bahwa pendidikan merupakan usaha sadar, bertujuan dan bersahabat untuk membimbing dan memperlengkapi individu dan kelompok menuju ke arah kedewasaan, khususnya dalam cara berpikir, sikap iman dan perilaku peserta didik. Dalam proses mengajarkan iman Kristen bagi peserta didik, guru sebaiknya berperan sebagai fasilitator karena guru yang dahulu sebagai satu-satunya sumber pengetahuan bagi anak didik, hendak menyadari bahwa pengetahuan dapat diakses oleh peserta didik kapan dan di mana saja. $^{7}$ Guru sebagai fasilitator berfungsi sebagai media antara variabelvariabel di luar kelas dengan peserta didik dalam membantu proses belajar mengajar. Sebagai seorang guru yang dapat mengarahkan peserta didik yang masih melakukan konflik di dalam lingkungan dan belum percaya kepada Tuhan, maka guru wajib mengajarkan kepada mereka iman, supaya mereka bisa mengenal Tuhan di dalam diri mereka sebagai Tuhan dan Juruselamat di dalam hidupnya, karena Alkitab mengatakan bahwa, "Segala tulisan yang diilhamkan Allah memang

\footnotetext{
${ }^{6}$ Syamsul Yusuf, Psikologi Perkembangan Anak Remaja, (Bandung: Remaja Rosdakarya, 2009), 28

${ }^{7}$ Bobby Kurnia Putrawan dan Ramot Peter. "Jurnal Teologi Gracia Deo 2, no.2 (2020): 70-79. https://doi.org/10.46929/graciadeo.v2i2.38.
} 
bermanfaat untuk mengajar, untuk menyatakan kesalahan, untuk memperbaiki kelakuan dan untuk mendidik orang dalam kebenaran. Dengan demikian tiap-tiap manusia kepunyaan Allah diperlengkapi untuk perbuatan baik"- 2 Timotius 3:16-17.

Guru ini juga memiliki pengaruh penting yang sangat penting dalam kehidupan seorang peserta didik. Selain itu, guru juga bukan hanya sebagai pangajar sekaligus sebagai pembimbing yang memberikan suatu pengarahan yang menuntu peserta didik baik dari cita-cita maupun dalam kebaikan. Dalam sejarah pendidikan, guru merupakan sosok teladan bagi peserta didik, yang harus memiliki strategi dengan cara dalam mengajar. Dengan Perjanjian Baru, mengajar dapat dipahami dari pelayanan Yesus Kristus yang dapat membawa orang-orang kejalan kehidupan yang benar. Oleh karena itu, sebagai guru mengajar dan membentuk peserta didik dengan hati nurani.

Sebagai peserta didik ini lebih banyak belajar dari apa yang mereka lihat dari seorang guru, melalui kata-kata memang dapat menggerakan tetapi kalau melalui teladan itulah yang dapat menarik hati. Dalam pendidikan karakter ini sesungguhnya lebih merupakan tuntutan terutama bagi kalangan pendidik itu sendiri. Seorang guru itu harus tampil

menjadi pribadi yang bisa ditiru dan diteladani. Guru dituntut memiliki kepribadian yang menarik, dan konsisten dalam nilai dan moral yang sangat baik yang bisa dipengaruhi oleh peserta didik, baik dari lingkungan sekolah maupun di lingkungan masyarakat. Seorang guru tidak boleh bermain sandiwara, disekolah tampil yang berpengaruh sebagai orang baik, namun dimasyarakat tampil sebaliknya. Pemberian teladan itu harus berpengaruh pada perilaku yang dilakukan oleh guru karena kalau gurunya melakukan hal-hal yang buruk, maka peserta didiknya juga mengikuti. Oleh karena itu, yang diharapkan dari guru adalah konsisten dalam berperilaku baik, penuh perhatian, adil, toleran, dan bertanggung jawab.

Para guru menunjukkan keseriusan belajar, memahami aturan dan kebijakan sekolah, berperilaku baik dengan sesama guru, staf, peserta didik, dan bahkan orangtua murid. Selain itu harus optimisi memiliki rendah hati, memiliki keberanian, atau berbagai kebijakan lainnya yang dapat dicontoh dan dipengaruhi oleh peserta didik. Dengan demikian, tumpanan dalam pembentukan karakter ini yang dipengaruhi, tidak sekedar melalui apa yang dikatakan dalam pembelajaran didalam kelas, melainkan juga nilai yang ditampilkan dalam diri seorang guru dalam kehidupannya yang 
nyata baik didalam atau pun diluar kelas. Karakter seorang guru ini akan sangat menentukan pula warna kepribadian peserta didik supaya mudah dalam memahami nilai-nilai itu.

Menurut Doni Koesema A. pendidikan karakter memiliki pengaruh terhadap kepribadian peserta didik. Secara konsep teoristis untuk menilai pendidikan karakter adalah perilaku atau tindakan peserta didik itu sendiri bukan hanya dari segi siswa mampu memahami dari sebuah pengertian ataupun kata-kata. Hal tersebut memaparkan bahwa terdapat pengaruh antara pendidikan karakter dengan kepribadian siswa. Dimana dengan dukungan pendidik dan lingkungan sekolah dalam penerapan pendidikan karakter menjadi salah satu keberhasilan implementasi pendidikan karakter terhadap kepribadian siswa.

Pengaruh kompetensi kepribadian guru terhadap kepribadian peserta didik yaitu dalam kegiatan sekolah erat kaitannya dengan kepribadian guru yang tampak aktivitas disekolah, akan memberi pengaruh kepada kepribadian peserta didik, karena seorang guru dituntut tidak hanya mampu untuk memaknai pembelajaran yang dilakukan. Akan tetapi yang terpenting adalah bagaimana seseorang guru mengemas pembelajaran sebagai jembatan atau sarana membentuk kompetensi kepribadian diri dan mampu memberikan pengaruh perbaikan terhadap kualitas pribadi atau kepribadian peserta didik. Pada tuntutan tersebut akan memberikan dampak pengaruh kepada kepribadian peserta didik. Selain itu sosok guru yang memiliki kepribadian yang digugu dan ditiru, secara psikologi siswa akan lebih yakin apa yang disampaikan oleh guru akan ditiru menjadi kepribadian tersebut. $^{8}$

Karakter dan kemampuan para siswa yang ada dalam kelas sudah pasti memiliki perbedaan-perbeda dan tidak satupun mempunyai kesamaan satu dengan lainnya. Bila pun ada persamaan aspek yang sama, pasti ada perbedaan di aspek lainnya. Perbedaan inilah yang menjadi faktor pendukung untuk mewujudkan kualitas masing-masing individu. Ada beberapa karakter anak yang perlu diketahui para guru agar terlebih mengetahui keadaan peserta didiknya. Karena di dalam kelas ada terdapat banyak jumlah siswa dengan berbagai karakter yang berbeda-beda. Maka sebagai seorang guru harus dapat memahami karakter dari berbagai macam prilaku siswa. Karena berbeda perilaku, maka akan berbeda pula masalah yang akan ditimbulkan oleh

\footnotetext{
${ }^{8}$ Fadhlullah Irfan, Pengaruh pedidikan karakter dan kepribadian guru terhadap kepribadian siswa, (Bandung: Guepedia, 2021) 2021.
} 
siswa. Maka dari pada itu, guru harus mempunyai keahlian untuk memecahkan masalah yang ada dalam diri siswa tersebut, tanpa harus menimbulkan masalah yang lainnya.

Seorang guru pendidikan agama Kristen mempunyai beberapa peran yang sama dengan guru-guru lain, tetapi ada yang membedakan peran guru pendidikan agama Kristen dengan guru-guru lainnya, yaitu dalam pelaksanaan perannya guru pendidikan agama Kristen ini harus selalu mencerminkan iman Kristiani dalam kepribadian dan karakternya. Tentu hal ini pun menjadi bagian integral dari guru-guru lain di sekolah, lebih dari kewajibannya untuk mencerminkan iman dan karakter yang benar dalam dirinya, ia juga adalah motor dari terselenggaranya kurikulum pendidikan agama Kristen yang spesifik untuk "membawa keluar" (educare) naradidik dalam pemahaman dan penanaman nilai-nilai kekristenan yang seharusnya terwujud dalam Christ-likeness yang menjadi tujuan mutlak dari setiap pendidikan agama kristen. Ada pun beberapa peran guru pendidikan agama Kristen antara lain, sebagai sahabat bagi naradidiknya. Relasi yang terjalin antara guru dan naradidik merupakan hubungan pribadi yang mengasihi, memelihara, menolong, dan mengembangkan, sehingga ke duanya dapat bertumbuh bersama.
Artinya, baik naradidik atau pun guru sama-sama mengalami pertumbuhan di dalam Yesus Kristus, baik secara intelektual, spiritual, sosial, dan emosional. $^{9}$

Peran guru dalam proses pembelajaran pendidikan agama Kristen untuk meningkatkan minat belajar siswa mendapatkan respons yang positif meskipun tidak secara keseluruhan adalah sebagai berikut; pertama, guru memiliki peran sebagai motivator bagi siswa, memberi dorongan dari luar dengan motivasi yang membangun. Selain itu, guru juga menjadi Konselor bagi siswa didiknya siap mendengarkan apa yang menjadi pergumulan siswa baik secara pribadi maupun keluarga supaya hubungn secara emosional antara guru dan siswa dapat terjalin satu dengan lain. Kedua, guru menjadi fasilitator untuk siswa memfasilitasi dalam belajar baik itu ruangan maupun materi yang akan siap diajarkan kepada siswa. Dan guru juga menjadi mediator sebagai jembatan bagi siswa untuk mengerti materi yang akan diajarkan. Ketiga, metode dalam mengajar sangat mempengaruhi siswa untuk mengerti apa yang akan disampaikan oleh guru, seperti metode studi kasus dan tanya jawab, ceramah dan memiliki kemampuan

\footnotetext{
${ }^{9}$ Howard Hendricks, 7 Hukum Sang guru (Atlanta: Walk Through the Bible Ministries, 1987), 37.
} 
dalam mengelola kelas. Menggunakan metode secara bervariasi perlu diperhatikan seorang pengajar, tidak fokus dengan satu metode saja dengan demikian siswa tidak bosan belajar, dengan cara ini akan meningkatkan minat belajar siswa.

\section{Pembentukan karakter peserta didik}

Pembentukan karakter dalam lingkungan pendidikan dan sekolah, antara lain dapat dilakukan dengan menyosialisasikan kepada pendidik, peserta didik, dan pengelola sekolah. Maksudnya, pembangunan karakter peserta didik memang tidak hanya dapat dibentuk melalui pembelajaran di ruang kelas, tetapi juga suri keteladanan. Pendidikan karakter kepada peserta didik paling efektif jika dilakukan dengan cara ditularkan dengan melalui suri teladan. Oleh karena itu, agar siswa memiliki karakter bersih, maka kebersihan kelas dan lingkungan sekolah harus dijaga dan dikontrol, agar peserta didik memiliki karakter disiplin, maka pendidik beserta pengelola sekolah harus memberikan contoh disiplin, seperti tidak terlambat datang ke sekolah dan sebagainya. ${ }^{10}$

\footnotetext{
${ }^{10}$ H.B. Bafirman, Pembentukan Karakter Siswa, (Jakarta: Kencana,2016) 19-20; Edim Bahapol dan Youke Singal. "Mendidik Untuk Kehidupan Berdasarkan Kompetensi Guru Kristen Di Indonesia (Education For Life Based On Christian Teacher Competence In Indonesia)." QUAERENS: Journal of Theology and Christianity
}

Sekolah merupakan lembaga pendidikan yang diciptakan oleh masyarakat untuk menyediakan lingkungan belajar dan ruang belajar serta tempat menerima dan memberi pelajaran. Kegiatan pembelajaran diselenggarakan untuk membentuk watak/karakter, membangun pengetahuan, sikap dan kebiasaan-kebiasaan untuk meningkatkan mutu kehidupan peserta didik. Upaya pembentukan karakter bagi siswa disekolah perlu dilakukan secara terus menerus untuk meningkatkan karakter yang baik dalam rangka membentuk pola pikir dan perilaku seseorang dalam mencapai keberhasilan hidup yang lebih baik. ${ }^{11}$

Pusat pengembangan budaya dalam peningkatan kedisiplinan dan ketertiban di lingkungan sekolah memang sangatlah penting, karena hal ini sering kali terjadi pelanggaran kedisiplinan dan ketertiban yang dilakukan para siswa. Kedisiplinan dan ketertiban perlu kita atur dalam sebuah tatanan yang biasa kita sebut dengan tata tertib sekolah, adapun dibuatnya tata tertib tersebut memiliki dua tujuan yaitu tujuan khusus dan juga tujuan umum. Secara khusus memiliki tujuan supaya kepala sekolah bisa menciptakan suasana yang kondusif bagi semua warga sekolah,

Studies 2, no.1 (2020): 62-85. https://doi.org/10.46362/quaerens.v2i1.21.

${ }^{11}$ Suyanto, Pengembangan Pendidikan Karakter (Jakarta: Kemdikbud, 2017) 9 
supaya para guru bisa melaksanakan belajar mengajar dengan optimal dan supaya tercipta kerja sama di antara para orang tua dengan sekolah dalam mengembangkan tugas pendidikan. Sedangkan tujuan secara umumnya yaitu agar terlaksananya kurikulum secara baik, serta bisa menunjang peningkatan mutu pendidikan didalam sekolah. Sama halnya bagi pembentukan karakter seorang anak, memang butuh waktu dan komitmen dari orangtua dan sekolah atau guru jika memprioritaskan hal ini untuk mendidik anak menjadi pribadi yang berkarakter. Akan tetapi, Butuh waktu dan cinta dari lingkungan yang merupakan tempat dia bertumbuh. Jika kita taat dengan proses ini maka dampaknya bukan hanya kepada peserta didik, kepada kitapun berdampak positif, paling tidak karakter dalam kesabaran, toleransi, mampu memahami masalah dari sudut pandang yang berbeda, disiplin dan memiliki integritas atau ucapan dan tindakan sama terpancar dari sebagai orangtua ataupun guru. ${ }^{12}$

Secara lebih sederhana Lickona mendefinisikan pendidikan karakter sebagai pendidikan yang dipengaruhi

${ }^{12}$ Suratman, Pembinaan Mental, Fisik dan Disiplin. (Jakarta: LAN, 1999), 11; Sutrisno dan Christiani Hutabarat. "Orangtua Dan Teman Bermain Terhadap Perkembangan Sosial Anak (Parents and Playing Friends Toward Children Social Development)." QUAERENS: Journal of Theology and Christianity Studies 1, no.1 (2019): 28-55. https://doi.org/10.46362/quaerens.v1i1.15. dalam membentuk kepribadian peserta didik melalui budi pekerti, yang hasilnya terlihat dalam tindakan nyata peserta didik, yaitu tingkah laku yang baik, jujur, bertanggung jawab, adil, dan menghormati hak orang lain. Sedangkan Menurut Starrat bahwa dalam pengaruh pembentukan peserta didik melalui guru secara model perencanaan, melainkan pembentukan yang dilakukan peserta didik atas hidup mereka sendiri. Pembentukan karakter ini terjadi dalam berbagai pengaruh dan komunitas. Sekolah misalnya, dalam hal ini diandaikan menjadi tempat pengaruh pendidikan yang memungkinkan peserta didik secara sadar atau sengaja mengukir hidup mereka sendiri. ${ }^{13}$

Sebelum seorang guru dapat membentuk karakter peserta didik, guru harus mengenal dan memahami karakter dan keunikan peserta didik yang berbedabeda terlebih dahulu. Guru harus mengenal peserta didiknya satu persatu, caranya dapat melalui faktor fisiknya, intelektualnya, emosinya, keterampilannya dan lain sebagainya. Dalam menanamkan karakter yang baik, guru hendaknya bisa memberikan keteladalan, baik dalam bersikap maupun dalam berkata-kata. Karena hal tersebut bisa membuat anak cepat mengerti bagaimana berkarakter

\footnotetext{
${ }^{13}$ Sukiyat H., Strategi Implementasi Pendidikan Karakter, (Surabaya: CV. Jakad Media Publishing, 2020), 21.
} 
yang benar. ${ }^{14}$ Dengan mengarahkan, mengajarkan serta mengajaknya untuk ber etika yang baik, maka akan lebih efektif hasil dari pendidikan tersebut. Maka lama kelamaan kebiasaan tersebut akan terus bertahan dalam dirinya dan akan menjadi kebiasaan dalam kehidupan sehari-hari.

\section{Pentingnya pendidikan karakter pada peserta didik}

Pendidikan karakter merupakan bentuk kegiatan manusia yang di dalamnya terdapat suatu tindakan yang bisa berpengaruh dalam pembentukan karakter. Karakter ini sangat erat berhubungan dengan sikap dan perilaku manusia karena karakter ini yang sangat berpengaruh dalam pembeda antar manusia. proses pembentukan karakter ini pada seseorang dipengaruhi oleh faktor-faktor khas yang ada pada orang-orang bersangkutan yang disebut dengan faktor bawaan dan faktor lingkungan. Dengan karakter yang baik, sudah pasti kita bisa berfikir sebelum melakukan sesuatu, baik ucapan maupun perbuatan, baik buruknya seseorang dan tindakan manusia sangat berkaitan dengan karakter. Jadi, yang dimaksud dengan pendidikan karakter ini adalah suatu sistem yang menanamkan nilai-nilai karakter

\footnotetext{
${ }^{14}$ Edim Bahapol dan Youke Singal. "Mendidik Untuk Kehidupan Berdasarkan Kompetensi Guru Kristen Di Indonesia (Education For Life Based On Christian Teacher Competence In Indonesia)": 62-85.
}

kepada seseorang individu, yang meliputi: ilmu pengetahuan, kesadaran, kemauan dan tindakan untuk dapat melaksanakan nilai-nilai tersebut baik terhadap Tuhan, diri sendiri, orang lain dan lingkungannya. ${ }^{15}$

Karakter guru sangat penting dalam pembentukan karakter peserta didik, karena berinteraksi secara intensif di sekolah. Mengembangkan karakter peserta didik melalui ceramah akan gagal jika guru yang mengajar peserta didik tidak mengamalkan karakter utama yang disampaikan. Oleh karena itu, sekolah harus fokus pada pengembangan karakter para guru sebelum meminta menjadi pengajar dan pendidik karakter. Guru selalu membutuhkan penyegaran dan pengembangan karakter dirinya agar efektif dalam pengembangan karakter peserta didik. meskipun demikian, guru saja belum cukup untuk mencetak peserta didik-peserta didik berkarakter, perlu keteladanan dengan didukung budaya sekolah dalam menerapkan karakter pada rutinitas sekolah. Keteladanan dalam pendidikan merupakan metode yang paling meyakinkan keberhasilannya dalam mempersiapkan dan membentuk anak di dalam aspek moral, spiritual, dan sosial. Hal ini berarti pendidik merupakan contoh

\footnotetext{
${ }^{15}$ Darmawati Vega, Pentingnya Pendidikan Karakter bagi Peserta, (Medan : Pemantang Siantar, 2018 ) 109
} 
terbaik dalam pandangan peserta didik, karena segala tindak tanduk, sopan santun, cara berpakaian, dan tutur kata akan selalu diperhatikan. Menjadi teladan tidaklah mudah, guru mesti mempunyai pijakan nilai etika. Arthur menegaskan keteladanan guru perlu didukung dengan nilai etika yang baik sebagaimana pernyataan berikut ini. ${ }^{16}$

Pendidikan karakter ini menekankan etis spiritual untuk membentuk pribadi yang baik. Tujuan pentingnya pendidikan karakter menurut Foerster, adalah untuk pembentukan karakter yang terwujud dalam kesatuan esensial antara subjek dengan perilaku serta sikap yang dimilikinya. ${ }^{17}$ Sedangkan Karakter adalah pengualifikasian pribadi seseorang yang memberikan kesatuan serta kekuatan terhadap keputusan yang diambilnya. Oleh sebab itu karakter menjadi seperti bukti diri dari seseorang. Maka karakter ini sangat penting dalam setiap pribadi kehidupan seseorang baik dalam bersikap, etika, dan perilaku.

Manfaat karakter bagi peserta didik adalah seperti yang Tuhan katakana didalam Firmannya" kamu adalah garam dan kamu adalah terang" (Matius 5:13-16).

\footnotetext{
${ }^{16}$ Musfah Jejen, Analisis Kebijakan Pendidikan: Pendidikan Nirkreasi, (Jakarta: Republika, Sindo, Media Indonesia. 2016) 19

${ }^{17}$ Koesoema A. Doni, Pendidikan Karakter Strategi Mendidik di Zaman Global, (Jakarta: PT Grasindo, 2007) 234
}

Karakter ini tercermin dalam setiap tindakan-tindakan nyata dalam peserta didik pada umumnya. Manfaat kedua karakter bagi pelayanan adalah sebagaimana Rasul Paulus menasehati Timotius bahwa jadilah teladan kepada semua orang dan segala aspek kehidupanmu (1Timotius 4:11-16), artinya bahwa seseorang harus menghidupi apa yang diajarkan kepada orang lain, untuk dapat melayani dengan baik maka diperlukan karakter-karakter yang mudah ditundukkan kepada Kristus, arti yang ketiga ialah, karakter dapat membangun pribadi dengan sempurna, yakni sama seperti kehidupan Kristus. Selain itu, juga mencerminkan karakter Kristus di dalam kehidupan pribadi. Dalam Filipi 3:17, berkata "Saudara-saudara, ikutlah teladanku dan perhatikanlah mereka, yang hidup sama seperti kami yang menjadi teladanmu". Artinya, karakter merupakan bukti kedewasaan kita dalam menjalani kehidupan ini.

\section{KESIMPULAN}

Lewat penelitian ini dapat disimpulkan bahwa peran guru pendidikan agama Kristen dalam pembentukan karakter peserta didik di sekolah sangat terkait erat dengan guru yang harus menjadi teladan dengan memberi contoh yang baik kepada peserta didik bukan 
hanya sekedar mengajar dan memotivasi siswa saja, akan tetapi guru harus terlibat dalam membentuk peserta didik ini baik dalam perilaku, sikap, etika di dalam kehidupan di sekolah. Dalam hal ini sekolah, peran guru pendidikan agama Kristen yang positif akan memberikan kontribusi yang positif juga terhadap karakter peserta didik. Peran guru pendidikan agama Kristen membentuk karakter peserta didik yang positif lewat karakter religius, jujur, toleransi, disiplin, cinta tanah air, cinta damai, dan peduli sosial. Dalam peran guru pendidikan

\section{KEPUSTAKAAN}

Bafirman, H.B. Pembentukan Karakter Siswa. Jakarta: Kencana, 2016.

Bahapol, Edim dan Youke Singal. "Mendidik Untuk Kehidupan Berdasarkan Kompetensi Guru Kristen Di Indonesia (Education For Life Based On Christian Teacher Competence In Indonesia)." QUAERENS: Journal of Theology and Christianity Studies 2, no.1 (2020): 62-85. https://doi.org/10.46362/quaerens.v2i 1.21.

Djmarah, Syaifu Bahri. Guru dan Anak didik dalam Interaksi Edukatif. Jakarta: PT. Renika Cipta, 2005.

Fadhlullah, Irfan. Pengaruh Pendidikan Karakter dan Kepribadian Guru terhadap Kepribadian Siswa" Bandung: Guepedia, 2021.

Hendricks, Howard. 7 Hukum Sang Guru, Atlanta: Walk Through the Bible Ministries, 1987. agama Kristen pembentukan karakter peserta didik seorang guru perlu menunjukan contoh yang dapat ditiru dan dipratekkan oleh peserta didik. Guru pendidikan agama Kristen harus mengajarkan peserta didik tersebut dalam hal-hal yang dapat ditiru oleh peserta didik, contohnya seperti dalam menghadapi tantangan atau permasalahan di sekolah, maka guru harus menjadi pedoman dan contoh dalam menghadapi setiap permasalahan tersebut, seperti dalam hal kesabaran dan cara mengatasinya.

Koesoema, Doni A. Pendidikan Karakter Strategi Mendidik di Zaman Global, Jakarta: PT Grasindo, 2007.

Musfah, Jejen. Analisis Kebijakan Pendidikan: Pendidikan Nirkreasi, Jakarta: Republika, Sindo, Media lndonesia, 2016.

Putrawan, Bobby Kurnia dan Ramot Peter. "Jurnal Teologi Gracia Deo 2, no.2 (2020):

70-79. https://doi.org/10.46929/graciadeo.v2i 2.38 .

Rohani, Ahmad. Pengelolaan Pengajaran. Jakarta: Rineka Cipta, 2010.

Situmorang, Kasminton, Ardianto Lahagu, dan Benteng Martua Mahuraja Purba. "Pengaruh Guru dalam Membentuk Karakter." REAL DIDACHE: Jurnal Teologi dan Pendidikan Agama Kristen 4, no.2 (2019): 103-112. https://osf.io/spkuv/

Sugiyono. Metode Penelitian Kombinasi. Bandung: Alfabeta, 2011.

Sukiyat, H. "Strategi Implementasi Pendidikan Karakter" Surabaya: CV. Jakad Media Publishing, 2021. 
Suratman. Pembinaan Mental, Fisik dan Disiplin. Jakarta: LAN, 1999.

Sutrisno dan Christiani Hutabarat. "Orangtua Dan Teman Bermain Terhadap Perkembangan Sosial Anak (Parents and Playing Friends Toward Children Social Development)." QUAERENS: Journal of Theology and Christianity Studies 1, no.1 (2019): 28-55. https://doi.org/10.46362/quaerens.v1i1.15

Suyanto. Pengembangan Pendidikan Karakter" Jakarta: Kementerian Pendidikan dan Kebudayaan RI, 2017.

Telaumbanua, Arozatulo. Peranan Guru Pendidikan Agama Kristen dalam Membentuk Karakter Siswa" Jurnal Fidei Vol.1 No.2 (Desember 2018): 221-222.

https://doi.org/10.34081/fidei.v1i2.9.

Vega, Darmawati. Pentingnya Pendidikan karakter bagi Peserta Didik. Medan: Pemantang Siantar, 2018.

Widjaja, Imron dan Lasmaria Nami Simanungkalit. "Christian Religious Education Management, Government Service, In Cell Groups On The Quality Of The Faith Of Church Members In Indonesia Bethel Church Of Graha Pena." MAHABBAH: Journal of Religion and Education 1, no.1 (2020): 55-69. https://doi.org/10.47135/mahabbah.v1 i1.8.

Yusuf, Syamsul. Psikologi Perkembangan Anak Remaja" Bandung: Remaja Rosdakarya, 2009. 